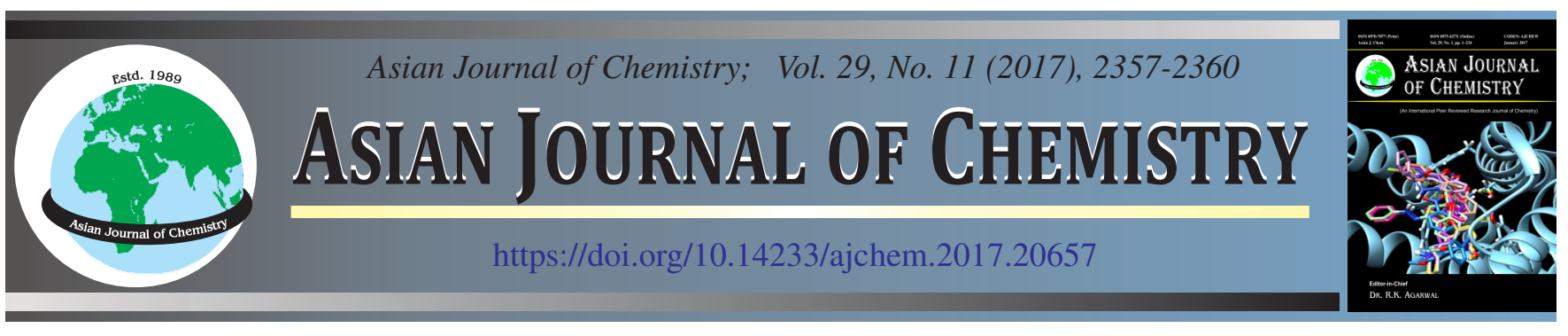

\title{
in vitro Antioxidant Activity and Total Phenolic Content of Rhizome Extracts from Acorus calamus Linn.
}

Pinky Chaubey, Archana, Om Prakash ${ }^{*}$, Kiran Rai, Ravendra Kumar and A.K. Pant

Department of Chemistry, College of Basic Sciences \& Humanities, G.B. Pant University of Agriculture \& Technology, Pantnagar-263 145, India

*Corresponding author: E-mail: oporgchem@gmail.com

Received: 18 March 2017;

Accepted: 31 May 2017;

Published online: 29 September 2017;

AJC-18549

The present study describes antioxidant activities of methanolic extracts from Acorus calamus (Araceae) rhizomes. The antioxidant
potential of methanolic extracts were determined by in vitro antioxidant screening models viz. DPPH radical scavenging activity, reductive
ability and metal chelating activity along with the estimation of total phenolics, flavonoids and ortho-dihydroxy contents. The total
phenolic, flavonoid and ortho-dihydroxy contents estimated ranged from $1.67 \pm 0.288$ to $10.42 \pm 0.180 \mathrm{mg} / \mathrm{g}$ gallic acid, $0.50 \pm 0.053$ to
$24.50 \pm 0.322 \mathrm{mg} / \mathrm{g}$ catechin and $0.43 \pm 0.145$ to $5.50 \pm 0.552 \mathrm{mg} / \mathrm{g}$ catechol, respectively among different locations. Sample $7^{\text {th }}$ was
found best for antioxidant activity (reducing power $119.42 \pm 0.630 \mu \mathrm{g} / \mathrm{mL}$ and $\mathrm{DPPH} 143.35 \pm 0.74 \mu \mathrm{g} / \mathrm{mL}$ ). The antioxidant activity of
the extracts were found to be positively correlated with phenolic content. However $\mathrm{IC}_{50}$ value exhibited negative correlation resulting $A$.
calamus is a possible potential source of natural antioxidant.

Keywords: Acorus calamus, Antioxidant activity, Total phenols.

ᄂ - - - - - - - - - - - - - - - - - - - - - - - - -

\section{INTRODUCTION}

Phenolic compounds found in plants have been well known for their ability of scavenging free radicals, which is referred to as antioxidant activity. Free radicals have a significant role in the processes of chemical materials degradation, food spoilage and also contribute to more human disorders in human beings. Antioxidants are widely used in dietary supplements and have been investigated for the prevention of diseases such as cancer and inflammatory diseases [1]. Antioxidants give protection to living organisms from damage caused by uncontrolled production of oxidative stress, concomitant lipid peroxidation, protein damage and DNA stand breaking [2]. Acorus calamus L. commonly known as 'Sweet flag' is a semiaquatic, tuberous perennial herb with creeping rhizomes, sword shaped leaves and spadix inflorescence, having a long history of medicinal use in different healthcare systems [3]. It is an aromatic medicinal plant, rich in alkaloids, phenolics and flavonoids as a potential source of compounds possessing beneficial biological activities. A. calamus is an integral part of the traditional Indian and Chinese systems of medicine and has a long history of use [4,5]. The rhizomes of A. calamus have been used to cure several diseases like asthma, fever, bronchitis and as a sedative [6]. The rhizomes of A. calamus and their essential oil are widely used in the flavouring industry.
The antioxidant activity of $A$. calamus extract is partly expected due to its one of the active constituents $\alpha$-asarone [7].

\section{EXPERIMENTAL}

The plants were collected from the twenty ecological niches of Uttarakhand in India. The plant material was taxonomically identified and authenticated by Dr. D.S. Rawat, Department of Biological Science, College of Basic Science and Humanities.

Preparation of extracts: The fresh rhizomes were shade dried and powdered. The powdered material was subjected for extraction in methanol by Soxhlet method. The extracts were evaporated with the help of rotatory vaccum evaporator and the final yield of the extract was weighed. The yield in percentage obtained has been recorded in Table-1.

Antioxidant activity: In present study, the in vitro antioxidant activity of the methanolic extract of rhizomes of A. calamus was evaluated by DPPH radical scavenging method; FRAP assay and metal chelating activity compared to standard antioxidant.

DPPH radical scavenging activity: DPPH scavenging activity was evaluated according to the method developed earlier and recently being used by Prakash et al. [8]. The assay mixture containing $5 \mathrm{~mL}$ of $0.004 \%$ methanol solution of DPPH and different amount of test sample solution of different concentrations. Inhibition of free radical by DPPH in percent (IC \%) 
TABLE-1

YIELD OF METHANOLIC EXTRACTS OBTAINED FROM THE RHIZOMES OF A. calamus OF DIFFERENT 20 ACCESSIONS

\begin{tabular}{cllcc}
\hline $\begin{array}{c}\text { S. } \\
\text { No. }\end{array}$ & Collection sites & \multicolumn{1}{c}{ District } & $\begin{array}{c}\text { Altitude } \\
(\mathrm{m})\end{array}$ & $\begin{array}{c}\text { Yield } \\
(\%)\end{array}$ \\
\hline 1 & Chhoi (1R) & Nainital & 369 & 1.3 \\
2 & Kotsari (2R) & Almora & 1750 & 2.7 \\
3 & Devlat(3R) & Paudi Garhwal & 1570 & 2.0 \\
4 & Saraikhet (4R) & Almora & 1850 & 1.5 \\
5 & Jaitpur (5R) & U.S.Nagar & 235 & 1.2 \\
6 & Paithani (6R) & Almora & 1100 & 0.8 \\
7 & Chaukhutiya (7R) & Almora & 1040 & 1.9 \\
8 & Rikherikhal(8R) & Paudi Garhwal & 1460 & 0.7 \\
9 & Jadaukhan (9R) & Pauri garhwal & 1740 & 0.7 \\
10 & Bageshwar(10R) & Bageshwar & 950 & 0.9 \\
11 & Someshwar(11R) & Almora & 1400 & 2.7 \\
12 & Palpur (12R) & Almora & 1500 & 1.7 \\
13 & Naulakot(13R) & Almora & 1540 & 1.7 \\
14 & Walka (14R) & Champawat & 1660 & 1.8 \\
15 & Gumti (15R) & Almora & 1550 & 1.3 \\
16 & Champawat(16R) & Champawat & 1670 & 2.2 \\
17 & Donprewa (17R) & Nainital & 345 & 1.7 \\
18 & Gairshen(18R) & Chamoli & 1620 & 2.3 \\
19 & Deghat (19R) & Almora & 1650 & 2.7 \\
20 & Khedagao(20R) & Almora & 1356 & 1.9 \\
\hline
\end{tabular}

was calculated by using the equation. IC $(\%)=[($ ControlSample)/Control] $\times 100$. Per cent inhibition was plotted against concentrations and the standard curve was drawn using standard antioxidant to calculate the $\mathrm{IC}_{50}$ values for standard and different extracts. A lower $\mathrm{IC}_{50}$ value indicated more radical scavenging activity.

Reducing power: The reducing power of methanolic extracts was determined by the method developed earlier with slight modifications [9]. Varying concentrations of tested sample were mixed with $2.5 \mathrm{~mL}$ of phosphate buffer $(200 \mathrm{mM}$, $\mathrm{pH}=6.6)$ and $2.5 \mathrm{~mL}$ of $1 \% \mathrm{~K}_{4}\left[\mathrm{Fe}(\mathrm{CN})_{6}\right]$. After incubation, $2.5 \mathrm{~mL}$ of trichloroacetic acid was added to the mixtures, followed by centrifugation at $650 \mathrm{rpm}$ for $10 \mathrm{~min}$. The upper layer was mixed with $5 \mathrm{~mL}$ distilled water and $1 \mathrm{~mL}$ of $0.1 \% \mathrm{FeCl}_{3}$ and absorbance of the resultant solution were measured at $700 \mathrm{~nm}$ using Thermo Scientific UV spectrophotometer. The reducing power (RP) of samples was calculated using the following formula:

$$
\mathrm{RP}(\%)=\frac{(\text { Control }- \text { Sample })}{\text { Control }} \times 100
$$

Percent inhibition was plotted against concentrations and the standard curve was drawn using standard antioxidant (BHT) to calculate the $\mathrm{RP}_{50}$ values for standard and different extracts. The lower $\mathrm{RP}_{50}$ value indicated greater reducing power ability.

Metal chelating activity: The metal chelating activity of $\mathrm{Fe}^{2+}$ was examined by the methods, recently being practiced [10] and based on the principle of the $\mathrm{Fe}^{2+}$ chelating ability the absorbance of ferrous iron-ferrozine complex formed is measured at $562 \mathrm{~nm} .0 .1 \mathrm{~mL}$ of $2 \mathrm{mM} \mathrm{FeCl}_{2} \cdot 4 \mathrm{H}_{2} \mathrm{O}, 0.2 \mathrm{~mL}$ of $5 \mathrm{mM}$ ferrozine and $4.7 \mathrm{~mL}$ of methanol was added to different concentrations of test samples $(50-250 \mu \mathrm{g} / \mathrm{mL})$. After incubation, the absorbances of test samples were measured at 562 $\mathrm{nm}$. The percent of chelating ability was plotted against concen- trations and the standard curve was drawn using standard antioxidant (EDTA) to calculate the $\mathrm{IC}_{50}$ values.

Total phenolic content: Phenolic compounds are plant metabolites, which contain several biological properties such as antitumor, antibacterial and antimutagenic. These properties might be related to their antioxidant capacity [11]. The total phenolics were determined by Folin-Ciocalteu method [12]. The standard curve was established using various concentrations of catechol and results were expressed as mg of catechol per gram of sample in dried weight.

Total flavonoid content: Plant extract was dissolved in $10 \mathrm{~mL}$ of desired solvent to prepare stock solution. $0.1 \mathrm{~mL}$ of stock solution was mixed with $1.25 \mathrm{~mL}$ water and $0.75 \mathrm{~mL}$ of $5 \% \mathrm{NaNO}_{2}$. After incubation, $0.15 \mathrm{~mL}$ of $10 \% \mathrm{AlCl}_{3}$ was added to the mixtures. After $6 \mathrm{~min}, 0.5 \mathrm{~mL}$ of $1 \mathrm{~N} \mathrm{NaOH}$ and $275 \mu \mathrm{L}$ of distilled water was added. After proper mixing of the solution the intensity of pink colour was obtained at 510 $\mathrm{nm}$. The flavanol content standard curve was established using various concentrations of catechin and the concentrations were calculated with the help of calibration curve and expressed in $\mathrm{mg} / 100 \mathrm{~g}$ of dry material [13].

ortho-Dihydric contents: Extract was dissolved in $10 \mathrm{~mL}$ desired solvent, $0.1 \mathrm{~mL}$ of the extract solution was mixed with $0.4 \mathrm{~mL}$ water and $1 \mathrm{~mL}$ of $0.05 \mathrm{~N} \mathrm{HCl}, 1 \mathrm{~mL}$ of Arnow's reagent, $10 \mathrm{~mL}$ of water and $2 \mathrm{~mL}$ of $1 \mathrm{~N} \mathrm{NaOH}$. The solution were mixed thoroughly (pink colour was appeared) and absorbance at 515 $\mathrm{nm}$ was measured. To calculate the amount of ortho-dihydric phenols present in the sample standard curve was prepared with the help of working standard catechol solution at different concentrations. The concentration were calculated from the calibration curve and expressed in $\mathrm{mg} / 100 \mathrm{~g}$ of material [14].

Statistical analysis: All the experiments were conducted in triplicates and the results were analyzed as mean \pm SD (Standard deviation). Statistical analysis was performed using SPSS16 (Statistical Package for the Social Science).

\section{RESULTS AND DISCUSSION}

The biological properties of the plants are considered in an estimation of the medicinal and nutritional values of medicinal plants. Natural antioxidants are responsible for preventing the oxidative stress and much safer to use due to its less toxicity and side effect. Antioxidants play a major role for prevention of tissue damage that stimulates the wound healing process [1]. Antioxidant properties of methanolic extracts of rhizomes of A. calamus are presented in Table- 2 .

Reducing power: The reductive capability of a compound may act as a remarkable indicator of its antioxidant potential [15]. Methanolic extracts of rhizomes of A. calamus showed higher reductive ability which was effective for neutralizing the free radical [3]. All the extracts exhibited good reducing power activity in a dose dependent manner with different potential. The reducing power activity is due to the presence of reductones (phenolics) [16]. In this study, $\mathrm{Fe}^{3+}$ to $\mathrm{Fe}^{2+}$ reducing activity exhibited the antioxidant ability in terms of their $\mathrm{RP}_{50}$ values (Table-2). The maximum reducing power observed in sample $15 \mathrm{R}\left(\mathrm{IC}_{50}=104.62 \pm 0.922 \mu \mathrm{g} / \mathrm{mL}\right)$ while $20 \mathrm{R}\left(\mathrm{IC}_{50}\right.$ $=241.81 \pm 0.762 \mu \mathrm{g} / \mathrm{mL})$ exhibit lowest reducing power activity. The $\mathrm{IC}_{50}(\mu \mathrm{g} / \mathrm{mL})$ increases in the order of BHT < 
TABLE-2

PHENOLIC CONTENT AND ANTIOXIDANT ACTIVITY IN Acorus calamus L.

\begin{tabular}{|c|c|c|c|c|c|c|c|}
\hline \multirow{2}{*}{$\begin{array}{l}\text { S. } \\
\text { No. }\end{array}$} & \multirow[b]{2}{*}{ Extracts } & \multirow{2}{*}{$\begin{array}{l}\text { Total phenols } \\
\text { (mg/g gallic acid) }\end{array}$} & \multirow{2}{*}{$\begin{array}{c}\text { Flavonols } \\
\text { (mg/g catechin) }\end{array}$} & \multirow{2}{*}{$\begin{array}{l}\text { ortho-Dihydric } \\
\text { phenol } \\
\text { (mg/g catechol) }\end{array}$} & \multicolumn{3}{|c|}{ Antioxidant assay } \\
\hline & & & & & $\begin{array}{l}\text { Reducing power } \\
\mathrm{RP}_{50}(\mu \mathrm{g} / \mathrm{mL})\end{array}$ & $\begin{array}{c}\text { DPPH IC } \\
(\mu \mathrm{g} / \mathrm{mL})\end{array}$ & $\begin{array}{l}\text { Fe chelating } \\
\mathrm{IC}_{50}(\mu \mathrm{g} / \mathrm{mL})\end{array}$ \\
\hline 1 & $1 \mathrm{R}$ & $2.46 \pm 0.040^{\mathrm{abc}}$ & $7.50 \pm 0.311^{\mathrm{de}}$ & $1.59 \pm 0.142^{\mathrm{bc}}$ & $114.80 \pm 0.645^{\mathrm{bc}}$ & $663.19 \pm 0.836^{\mathrm{p}}$ & $324.68 \pm 2.992^{\mathrm{d}}$ \\
\hline 2 & $2 \mathrm{R}$ & $4.67 \pm 0.754^{\mathrm{d}}$ & $10.00 \pm 0.740^{\mathrm{gh}}$ & $1.87 \pm 0.030^{\mathrm{bcd}}$ & $142.73 \pm 1.918^{g}$ & $281.26 \pm 0.885^{\mathrm{i}}$ & $934.74 \pm 8.631^{q}$ \\
\hline 3 & $3 R$ & $1.92 \pm 0.171^{\mathrm{a}}$ & $13.50 \pm 0.464^{i}$ & $3.00 \pm 0.173^{\mathrm{def}}$ & $136.20 \pm 1.136^{\mathrm{f}}$ & $279.70 \pm 0.962^{\mathrm{i}}$ & $836.56 \pm 7.464^{\mathrm{n}}$ \\
\hline 4 & $4 \mathrm{R}$ & $3.92 \pm 1.100^{\text {bcd }}$ & $27.25 \pm 0.337^{1}$ & $1.39 \pm 0.155^{\mathrm{ab}}$ & $141.66 \pm 1.191^{\mathrm{g}}$ & $249.83 \pm 0.545^{f}$ & $916.70 \pm 0.558^{p}$ \\
\hline 5 & $5 \mathrm{R}$ & $2.33 \pm 0.481^{\mathrm{ab}}$ & $9.75 \pm 0.391^{\mathrm{gh}}$ & $3.37 \pm 0.010^{f}$ & $175.64 \pm 0.161^{j}$ & $221.44 \pm 0.676^{d}$ & $490.07 \pm 3.965^{j}$ \\
\hline 6 & $6 \mathrm{R}$ & $2.5 \pm 0.463^{\mathrm{abc}}$ & $8.00 \pm 0.688^{\mathrm{ef}}$ & $5.39 \pm 0.632^{\mathrm{g}}$ & $183.02 \pm 2.060^{\mathrm{k}}$ & $228.23 \pm 0.498^{e}$ & $1439.35 \pm 2.896^{\mathrm{s}}$ \\
\hline 7 & $7 \mathrm{R}$ & $4.42 \pm 0.294^{\mathrm{d}}$ & $9.75 \pm 0.261^{\mathrm{gh}}$ & $0.43 \pm 0.036^{\mathrm{a}}$ & $119.42 \pm 0.630^{d}$ & $143.35 \pm 0.741^{c}$ & $886.88 \pm 1.776^{\circ}$ \\
\hline 8 & $8 \mathrm{R}$ & $3.04 \pm 0.845^{\mathrm{abcd}}$ & $3.75 \pm 0.894^{\mathrm{b}}$ & $5.50 \pm 0.552^{\mathrm{g}}$ & $126.23 \pm 0.320^{\mathrm{e}}$ & $657.50 \pm 2.165^{\circ}$ & $360.80 \pm 2.077^{\mathrm{f}}$ \\
\hline 9 & $9 \mathrm{R}$ & $4.33 \pm 0.567^{\mathrm{d}}$ & $14.75 \pm 0.317^{\mathrm{ij}}$ & $0.43 \pm 0.145^{\mathrm{a}}$ & $171.50 \pm 0.547^{\mathrm{i}}$ & $379.18 \pm 1.339^{k}$ & $432.44 \pm 1.022^{\mathrm{h}}$ \\
\hline 10 & $10 \mathrm{R}$ & $7.08 \pm 0.466^{\mathrm{e}}$ & $9.25 \pm 0.166^{\mathrm{fg}}$ & $2.22 \pm 0.470^{\text {bcde }}$ & $165.25 \pm 0.346^{\mathrm{h}}$ & $281.23 \pm 0.836^{\mathrm{i}}$ & $377.43 \pm 3.275^{\mathrm{g}}$ \\
\hline 11 & $11 \mathrm{R}$ & $1.79 \pm 0.386^{a}$ & $24.50 \pm 0.322^{k}$ & $3.74 \pm 0.261^{\mathrm{f}}$ & $113.10 \pm 0.782^{b}$ & $606.07 \pm 0.128^{n}$ & $587.27 \pm 1.503^{1}$ \\
\hline 12 & $12 \mathrm{R}$ & $2.29 \pm 0.139^{\mathrm{ab}}$ & $0.50 \pm 0.053^{\mathrm{a}}$ & $1.09 \pm 0.044^{\mathrm{ab}}$ & $225.93 \pm 0.821^{1}$ & $662.04 \pm 0.291^{\mathrm{p}}$ & $371.35 \pm 3.316^{\mathrm{g}}$ \\
\hline 13 & $13 R$ & $10.42 \pm 0.180^{f}$ & $6.25 \pm 0.531^{\mathrm{cd}}$ & $1.61 \pm 0.170^{\mathrm{bc}}$ & $114.66 \pm 0.329^{\mathrm{bc}}$ & $372.85 \pm 1.009^{j}$ & $686.98 \pm 1.216^{\mathrm{m}}$ \\
\hline 14 & $14 \mathrm{R}$ & $8.54 \pm 0.580^{\mathrm{e}}$ & $5.25 \pm 0.601^{\mathrm{bc}}$ & $1.67 \pm 0.390^{\mathrm{bc}}$ & $117.51 \pm 0.446^{\mathrm{cd}}$ & $915.72 \pm 1.055^{\mathrm{r}}$ & $1121.06 \pm 1.892^{\mathrm{r}}$ \\
\hline 15 & $15 \mathrm{R}$ & $4.54 \pm 0.884^{\mathrm{d}}$ & $1.75 \pm 0.442^{\mathrm{a}}$ & $1.24 \pm 0.154^{\mathrm{ab}}$ & $104.62 \pm 0.922^{\mathrm{a}}$ & $735.71 \pm 0.416^{\mathrm{q}}$ & $531.85 \pm 1.508^{k}$ \\
\hline 16 & $16 \mathrm{R}$ & $7.29 \pm 0.128^{\mathrm{e}}$ & $16.25 \pm 0.367^{j}$ & $3.26 \pm 0.724^{\mathrm{ef}}$ & $170.62 \pm 0.695^{\mathrm{i}}$ & $272.28 \pm 0.593^{\mathrm{h}}$ & $335.27 \pm 2.295^{\mathrm{e}}$ \\
\hline 17 & $17 \mathrm{R}$ & $1.67 \pm 0.288^{\mathrm{a}}$ & $2.00 \pm 1.081^{\mathrm{a}}$ & $1.13 \pm 0.462^{\mathrm{ab}}$ & $118.32 \pm 0.786^{d}$ & $919.55 \pm 0.588^{\mathrm{s}}$ & $499.00 \pm 3.577^{j}$ \\
\hline 18 & $18 \mathrm{R}$ & $4.29 \pm 0.085^{d}$ & $8.50 \pm 0.227^{\mathrm{efg}}$ & $2.04 \pm 0.822^{\mathrm{bcd}}$ & $174.94 \pm 0.779^{j}$ & $382.43 \pm 0.193^{k}$ & $467.56 \pm 2.509^{i}$ \\
\hline 19 & $19 \mathrm{R}$ & $7.25 \pm 0.638^{\mathrm{e}}$ & $7.50 \pm 0.246^{\mathrm{de}}$ & $2.63 \pm 0.090^{\text {cdef }}$ & $174.74 \pm 0.278^{j}$ & $585.99 \pm 2.839^{\mathrm{m}}$ & $375.18 \pm 1.664^{g}$ \\
\hline 20 & $20 \mathrm{R}$ & $4.00 \pm 0.514^{\mathrm{cd}}$ & $11.25 \pm 0.225^{\mathrm{h}}$ & $2.00 \pm 0.171^{\mathrm{bcd}}$ & $241.81 \pm 0.762^{\mathrm{m}}$ & $549.31 \pm 2.976^{1}$ & $308.57 \pm 0.855^{c}$ \\
\hline 21 & $\mathrm{BHT}^{*}$ & - & - & - & $102.23 \pm 1.068^{\mathrm{a}}$ & $101.88 \pm 0.707^{b}$ & - \\
\hline 22 & EDTA* & - & - & - & - & - & $194.06 \pm 0.119^{\mathrm{a}}$ \\
\hline 23 & Citric acid* & - & - & - & - & - & $207.56 \pm 0.470^{b}$ \\
\hline 24 & Catechin $^{*}$ & - & - & - & - & $64.08 \pm 0.406^{\mathrm{a}}$ & - \\
\hline
\end{tabular}

* = Standard antioxidants, $-=$ Not applicable, Values are means of three replicates \pm SD. Within a column, mean values followed by the same letter are not significantly different according to Tukey's test $(\mathrm{p}<0.05)$.

$15 \mathrm{R}<11 \mathrm{R}<13 \mathrm{R}<1 \mathrm{R}<14 \mathrm{R}<17 \mathrm{R}<7 \mathrm{R}<8 \mathrm{R}<3 \mathrm{R}<4 \mathrm{R}<$ $2 \mathrm{R}<10 \mathrm{R}<16 \mathrm{R}<9 \mathrm{R}<19 \mathrm{R}<18 \mathrm{R}<5 \mathrm{R}<6 \mathrm{R}<12 \mathrm{R}<20 \mathrm{R}$.

DPPH radical scavenging activity: The DPPH antioxidant activity is based on the capability of DPPH a stable free radical, which is discoloured in the presence of antioxidants [17]. Dose dependent DPPH radical scavenging activity was found in all the extracts in comparison to the standard antioxidants BHT and catechin. Maximum antioxidant activity (DPPH assay) was observed in $7 \mathrm{R}\left(\mathrm{IC}_{50}=143.35 \pm 0.741 \mu \mathrm{g} / \mathrm{mL}\right)$ while $17 \mathrm{R}\left(\mathrm{IC}_{50}=919.55 \pm 0.588 \mu \mathrm{g} / \mathrm{mL}\right)$ exhibited lowest radical scavenging activity.

Metal chelating activity: The antioxidant ability of the plant extract depends on both the composition and test system. The ferrous ion-chelating activity of $A$. calamus leaf and rhizome extracts can be attributed to their total phenolic content [18]. In the present study the $\mathrm{Fe}^{2+}$ chelating activity of methanolic extracts also expressed in terms of their $\mathrm{IC}_{50}$ values (Table-2), which reveals that the maximum antioxidant activity (metal chelating) was observed in $20 \mathrm{R}\left(\mathrm{IC}_{50}=308.57 \pm 0.855 \mu \mathrm{g} / \mathrm{mL}\right)$ while $6 \mathrm{R}\left(\mathrm{IC}_{50}=1439.35 \pm 2.896 \mu \mathrm{g} / \mathrm{mL}\right)$ showed minimum chelating activity.

Total phenolic content: Methanolic extract of A. calamus rhizomes were studied quantitatively in terms of their total phenolic content with the help of their respective calibration curves obtained calorimetrically. The antioxidant properties of different extracts were found to be due to the presence of phenols and hydrogen donating molecules in the extracts. Total phenolic content (Tables 2 and 3 ) showed the variation ranging from $1.67-10.42 \mathrm{mg} / \mathrm{g}$ gallic acid and a major significant positive relationship with antioxidant activity.
TABLE-3

TOTAL PHENOLIC CONTENT OF Acorus calamus L.

\begin{tabular}{|c|c|c|c|c|}
\hline $\begin{array}{l}\text { S. } \\
\text { No. }\end{array}$ & Extracts & $\begin{array}{l}\text { Total phenols } \\
\text { (mg/g gallic } \\
\text { acid) }\end{array}$ & $\begin{array}{l}\text { Flavonols } \\
\text { (mg/g } \\
\text { catechin) }\end{array}$ & $\begin{array}{c}\mathrm{ODP}(\mathrm{mg} / \mathrm{g} \\
\text { catechol })\end{array}$ \\
\hline 1 & $1 \mathrm{R}$ & $2.46 \pm 0.040^{\mathrm{abc}}$ & $7.50 \pm 0.311^{\mathrm{de}}$ & $1.59 \pm 0.142^{\mathrm{bc}}$ \\
\hline 2 & $2 \mathrm{R}$ & $4.67 \pm 0.754^{d}$ & $10.00 \pm 0.740^{g h}$ & $1.87 \pm 0.030^{\mathrm{bcd}}$ \\
\hline 3 & $3 R$ & $1.92 \pm 0.171^{\mathrm{a}}$ & $13.50 \pm 0.464^{\mathrm{i}}$ & $3.00 \pm 0.173^{\text {def }}$ \\
\hline 4 & $4 \mathrm{R}$ & $3.92 \pm 1.100^{\mathrm{bcd}}$ & $27.25 \pm 0.337^{1}$ & $1.39 \pm 0.155^{\mathrm{ab}}$ \\
\hline 5 & $5 \mathrm{R}$ & $2.33 \pm 0.481^{\mathrm{ab}}$ & $9.75 \pm 0.391^{\mathrm{gh}}$ & $3.37 \pm 0.010^{f}$ \\
\hline 6 & $6 \mathrm{R}$ & $2.5 \pm 0.463^{\mathrm{abc}}$ & $8.00 \pm 0.688^{\text {ef }}$ & $5.39 \pm 0.632^{\mathrm{g}}$ \\
\hline 7 & $7 \mathrm{R}$ & $4.42 \pm 0.294^{\mathrm{d}}$ & $9.75 \pm 0.261^{\text {gh }}$ & $0.43 \pm 0.036^{\mathrm{a}}$ \\
\hline 8 & $8 \mathrm{R}$ & $3.04 \pm 0.845^{\text {abcd }}$ & $3.75 \pm 0.894^{b}$ & $5.50 \pm 0.552^{\mathrm{g}}$ \\
\hline 9 & $9 \mathrm{R}$ & $4.33 \pm 0.567^{d}$ & $14.75 \pm 0.317^{\mathrm{ij}}$ & $0.43 \pm 0.145^{\mathrm{a}}$ \\
\hline 10 & $10 \mathrm{R}$ & $7.08 \pm 0.466^{\mathrm{e}}$ & $9.25 \pm 0.166^{\mathrm{fg}}$ & $2.22 \pm 0.470^{\text {bcde }}$ \\
\hline 11 & $11 \mathrm{R}$ & $1.79 \pm 0.386^{\mathrm{a}}$ & $24.50 \pm 0.322^{k}$ & $3.74 \pm 0.261^{\mathrm{f}}$ \\
\hline 12 & $12 \mathrm{R}$ & $2.29 \pm 0.139^{\mathrm{ab}}$ & $0.50 \pm 0.053^{\mathrm{a}}$ & $1.09 \pm 0.044^{\mathrm{ab}}$ \\
\hline 13 & $13 R$ & $10.42 \pm 0.180^{f}$ & $6.25 \pm 0.531^{\mathrm{cd}}$ & $1.61 \pm 0.170^{b c}$ \\
\hline 14 & $14 \mathrm{R}$ & $8.54 \pm 0.580^{\mathrm{e}}$ & $5.25 \pm 0.601^{\mathrm{bc}}$ & $1.67 \pm 0.390^{\mathrm{bc}}$ \\
\hline 15 & $15 \mathrm{R}$ & $4.54 \pm 0.884^{\mathrm{d}}$ & $1.75 \pm 0.442^{\mathrm{a}}$ & $1.24 \pm 0.154^{\mathrm{ab}}$ \\
\hline 16 & $16 \mathrm{R}$ & $7.29 \pm 0.128^{\mathrm{e}}$ & $16.25 \pm 0.367^{j}$ & $3.26 \pm 0.724^{\mathrm{ef}}$ \\
\hline 17 & $17 \mathrm{R}$ & $1.67 \pm 0.288^{\mathrm{a}}$ & $2.00 \pm 1.081^{\mathrm{a}}$ & $1.13 \pm 0.462^{\mathrm{ab}}$ \\
\hline 18 & $18 \mathrm{R}$ & $4.29 \pm 0.085^{\mathrm{d}}$ & $8.50 \pm 0.227^{\mathrm{efg}}$ & $2.04 \pm 0.822^{\text {bcd }}$ \\
\hline 19 & $19 \mathrm{R}$ & $7.25 \pm 0.638^{\mathrm{e}}$ & $7.50 \pm 0.246^{\mathrm{de}}$ & $2.63 \pm 0.090^{\text {cdef }}$ \\
\hline 20 & $20 \mathrm{R}$ & $4.00 \pm 0.514^{\text {cd }}$ & $11.25 \pm 0.225^{\mathrm{h}}$ & $2.00 \pm 0.171^{\mathrm{bcd}}$ \\
\hline
\end{tabular}

Values are means of three replicates \pm SD. Within a column, mean values followed by the same letter are not significantly different according to Tukey's test $(\mathrm{p}<0.05)$.

Total phenolic content and antioxidant activity varied among the populations and solvent system. Solvents with medium polarity such as methanol and acetone were found best for extraction of total phenolic content and antioxidant ability [19]. 
TABLE-4

CORRELATION BETWEEN ALTITUDE, PHENOLIC CONTENT AND ANTIOXIDANT ACTIVITIES IN A. calamus L.

\begin{tabular}{|c|c|c|c|c|c|c|c|}
\hline & Altitude & $\begin{array}{c}\text { Total } \\
\text { phenols }\end{array}$ & Flavonoid & $\begin{array}{l}\text { ortho-Dihydric } \\
\text { phenol }\end{array}$ & $\begin{array}{c}\text { Reducing } \\
\text { power assay } \\
\mathrm{P}_{50}(\mu \mathrm{g} / \mathrm{mL})\end{array}$ & $\begin{array}{l}\text { DPPH assay } \\
\mathrm{IC}_{50}(\mu \mathrm{g} / \mathrm{mL})\end{array}$ & $\begin{array}{c}\text { Metal chelating } \\
\text { assay } \\
\mathrm{IC}_{50}(\mu \mathrm{g} / \mathrm{mL})\end{array}$ \\
\hline Altitude & 1 & & & & & & \\
\hline Total phenols & 0.400 & 1 & & & & & \\
\hline Flavonoid & 0.285 & -0.094 & 1 & & & & \\
\hline ortho-Dihydric phenol & -0.038 & -0.205 & 0.081 & 1 & & & \\
\hline Reducing power assay & 0.103 & -0.101 & -0.024 & 0.072 & 1 & & \\
\hline DPPH assay & -0.084 & -0.053 & $-0.467 *$ & -0.128 & -0.223 & 1 & \\
\hline Metal chelating assay & 0.159 & 0.030 & 0.134 & 0.155 & -0.246 & -0.256 & 1 \\
\hline
\end{tabular}

In the present study, results showed negative correlation between total phenols and $\mathrm{IC}_{50}$ value of DPPH scavenging and reducing power activity. Maximum total flavonoid content was observed in $4 \mathrm{R}(27.25 \mathrm{mg} / \mathrm{g}$ catechin) while $12 \mathrm{R}(0.50 \mathrm{mg} / \mathrm{g}$ catechin $)$ exhibited lowest flavonoid content. The ortho-dihydric phenol (ODP) content was found in the range of 0.43 to $5.50 \mathrm{mg} / \mathrm{g}$ catechol in which $8 \mathrm{R}$ has the highest ODP content followed by the other extracts. Previous studies have showed the phenolic content is (4.90 mg GAE/g dw) in same species of methanolic extract [20] whereas $12.45 \mathrm{mg} \mathrm{GAE} / \mathrm{g}$ dw to $23.4 \mathrm{mg} \mathrm{GAE} /$ $100 \mathrm{~g} \mathrm{dw}$ phenolic content have also been reported earlier $[21,22]$. These data indicate that various factors such as climatic conditions, growth stage and genetic make-up influence the total phenolic content of plant [23]. The essential oil composition of $A$. calamus has already been reported from our laboratory [24]. The oil was found to be rich in phenylpropanoids, $Z$ - $\beta$ asarone and $E$ - $\beta$-asarone, which were identified as major constituents of $A$. calamus. The previous study in our lab also revealed the antibacterial activity of rhizome essential oil and $\beta$-asarone from $A$. calamus [25]. The analysis revealed that DPPH scavenging activity and reductive ability were highly correlated with the phenolic and flavonoid content of the extracts, which showed promising sources of antioxidant activity. Altitudes are positively associated with total phenols and flavonoid content while, no significant relationship with altitude and antioxidant activity was observed (Table-4).

\section{Conclusion}

In this study, an investigation on antioxidant activity of A. calamus provides a validation for the traditional use of these plants. Finally, it can be concluded that methanolic extracts of A. calamus exhibit free radical scavenging activity, reducing power and metal chelating activity and the plants may be considered as a good source of natural antioxidant for medicinal purposes.

\section{ACKNOWLEDGEMENTS}

The authors are thankful to DST, New Delhi, India for financial assistance. The authors also thanks G.B. Pant University of Agriculture and Technology, Pantnagar, India is thankfully acknowledged for providing the laboratory facilities.

\section{REFERENCES}

1. V.Y.A. Barku, Y. Opoku-Boahen, E. Owusu-Ansah and E.F. Mensah, Asian J. Plant Sci. Res., 3, 69 (2013).
2. R. Srinivasan, M.J.N. Chandrasekar, M.J. Nanjan and B. Suresh, J. Ethnopharmacol., 113, 284 (2007); https://doi.org/10.1016/j.jep.2007.06.006.

3. S. Manju, R.P. Chandran, P.K. Shaji and G.A. Nair Int. J. Pharm. Pharm. Sci., 5, 4 (2013).

4. H.S. Wu, D.F. Zhu, C. Zhou, C.-R. Feng, Y.-J. Lou, B. Yang and Q.-J. He, J. Ethnopharmacol., 123, 288 (2009); https://doi.org/10.1016/j.jep.2009.03.004.

5. M.-H. Lee, Y.-Y. Chen, J.-W. Tsai, S.-C. Wang, T. Watanabe and Y.-C. Tsai, Food Chem., 126, 1 (2011); https://doi.org/10.1016/j.foodchem.2010.08.052.

6. R. Balakumbahan, K. Rajamani and K. Kumanan, J. Med. Plants Res., 4, 2740 (2010).

7. S. Manikandan and R.S. Devi, Pharmacol. Res., 52, 467 (2005); https://doi.org/10.1016/j.phrs.2005.07.007.

8. O. Prakash, M. Gondwal and A.K. Pant, Indian J. Nat. Prod. Resour., 2, 4 (2011)

9. G.S. Jeena, H. Punetha, O. Prakash, M. Chandra and K.P.S. Kushwaha, Indian J. Nat. Prod., 5, 56 (2014).

10. G. Kunwar, O. Prakash, M. Chandra and A.K. Pant, Asian J. Tradit. Med., 8, 88 (2013).

11. G. Shui and L.P. Leong, J. Chromatogr. A, 977, 89 (2002); https://doi.org/10.1016/S0021-9673(02)01345-6.

12. K. Shetty, O.F. Curtis, R.E. Levin, R. Witkowsky and W. Ang, J. Plant Physiol., 147, 447 (1995); https://doi.org/10.1016/S0176-1617(11)82181-4.

13. Y.M. Choi, D.O. Noh, S.Y. Cho, H.J. Suh, K.M. Kim and J.M. Kim, LWT-Food Sci. Technol., 39, 756 (2006); https://doi.org/10.1016/j.1wt.2005.05.015.

14. A. Mahadevan and R. Sridhar, In: Methods in Physiological Plant Pathology, Sivikami Publication, Chennai, India, edn 3, pp. 190-192 (1986).

15. P. Jayanthi and P. Lalitha, Int. J. Pharm. Pharm. Sci., 3, 126 (2011).

16. B.L. Nanda, G.S.N. Sultana and T.T. Radhakrishnan, J. Drug Deliv. Ther., 4, 6 (2014).

17. K. Subathraa and T.V. Poonguzhali, Int. J. Curr. Sci., 10, 169 (2012).

18. S.A. Devi and D. Ganjewala, J. Herbs Spices Med. Plants, 17, 1 (2011); https://doi.org/10.1080/10496475.2010.509659.

19. A. Bahukhandi, S. Rawat, I.D. Bhatt and R.S. Rawal, Natl. Acad. Sci. Lett., 36, 93 (2013);

https://doi.org/10.1007/s40009-012-0109-8.

20. S. Surveswaran, Y. Cai, H. Corke and M. Sun, Food Chem., 102, 938 (2007); https://doi.org/10.1016/j.foodchem.2006.06.033.

21. F. Ahmed, N.S.J.N. Chandra, A. Urooja and K.S. Rangappa, J. Pharm. Res., 2, 830 (2009).

22. A. Wojdylo, J. Oszmianski and R. Czemerys, Food Chem., 105, 940 (2007); https://doi.org/10.1016/j.foodchem.2007.04.038.

23. V. Kondakova, I. Tsvetkov, R. Batchvarova, I. Badjakov, T. Dzhambazova and S. Slavov, Biotechnol. Biotechnol. Equip., 23, 1444 (2009); https://doi.org/10.2478/V10133-009-0024-4.

24. R. Kumar, O. Prakash, A.K. Pant, S.K. Hore, C.S. Chanotiya and C.S. Mathela, Nat. Prod. Commun., 4, 275 (2009).

25. N. Joshi, O. Prakash and A.K. Pant, J. Essential Oil Bearing Plants, 15, 32 (2012);

https://doi.org/10.1080/0972060X.2012.10644016. 